\title{
NEUROLOGICAL MANIFESTATIONS OF CELIAC DISEASE
}

\author{
José Ibiapina Siqueira Netoㅁ, Ana Carolina Leite Vieira Costa², \\ Francisco George Magalhães ${ }^{3}$, Gisele Sampaio Silva ${ }^{4}$
}

\begin{abstract}
Celiac disease (CD/ Nontropicalsprue, gluten-sensitive enteropathy) is a malabsortive condition in which an allergic reaction to the cereal grain-protein gluten (present in wheat, rye and barley) causes small intestine mucosal injury. The onset is in the first four decades of life, with a female to male ratio of 2:1. It may be associated with a wide spectrum of neurological manifestations including cerebellar ataxia, epileptic seizures, dementia, neuropathy, myopathy and multifocal leucoencephalopathy. We report three patients with neurological manifestations related with CD: one with cerebellar ataxia, one with epilepsy and one with cognitive impairment. The diagnosis of $C D$ was confirmed by serologic tests (antiendomysial and antigliadin antibodies) and biopsy of the small intestine. In two patients the neurological symptoms preceded the gastrointestinal abnormalities and in all of them gluten restriction failed to improve the neurological disability. Conclusion: CD should be ruled out in the differential diagnosis of neurological dysfunction of unknown cause, including ataxia, epilepsy and dementia. A gluten free diet, the mainstay of treatment, failed to improve the neurological disability.
\end{abstract}

KEY WORDS: celiac disease, cerebellar ataxia, epilepsy, cognitive impairment.

\begin{abstract}
Manifestações neurológicas da doença celíaca
RESUMO - A doença celíaca (DC, enteropatia sensível ao glúten) é desordem caracterizada por mal absorção causada por reação alérgica ao glúten, proteína presente em diversoscereais. Asmanifestaçõesiniciaisocorrem nas primeiras quatro décadas de vida, sendo cerca de duas vezes mais freqüente no sexo feminino. DC pode estar associada a largo espectro de manifestações neurológicas incluindo ataxia cerebelar, epilepsia, demência, neuropatia, miopatia e leucoencefalopatia multifocal. Relatamostrês casos de pacientescom manifestações neurológicas da DC: um com ataxia cerebelar, outro com epilepsia e o último com déficit cognitivo. O diagnóstico de DC foi estabelecido com base em testes sorológicos (anticorpos antiendomísio e antigliadina) e biópsia intestinal. Em dois pacientes as alterações neurológicas precederam as gastrointestinais. Em todosos casos a dieta livre de glúten não influenciou o quadro neurológico. Concluímos que o diagnóstico de DC deve ser considerado em pacientes com alterações neurológicas de etiologia indeterminada, incluindo ataxia, epilepsia e demência. Uma dieta sem glúten, a base do tratamento das manifestações gastrointestinais, não foi eficiente em melhorar os sintomas neurológicos em nossos pacientes.
\end{abstract}

PALAVRAS-CHAVE: doença celíaca, ataxia cerebelar, epilepsia.

Celiac disease (CD) is an autoimmune disease of the small intestine precipitated by the ingestion of gluten in genetically susceptible individuals. The true prevalence is difficult to ascertain since many patients have atypical symptoms. Studies in both Europe and North America estimate the seroprevalence to be 1 of every 120 to 300 persons ${ }^{1,2}$. The symptoms of CD may appear with the introduction of cereals in an infant's diet or may first become evident in adulthood. Classic signs are related to the gastrointestinal tract. Extraintestinal manifesta- tions include anemia, coagulopathy, metabolic bone diseases, infertility ${ }^{1}$, psychiatric syndromes ${ }^{3}$ and various neurological disorders 4 . The diagnosis of CD isbased on serologic tests (antiendomysial, antigliadin and antitransglutaminase antibodies) and on characteristic histopathological changes (villousatrophy, crypt hyperplasia and inflammatorycell infiltrates) seen on distal duodenal biopsy, the gold standard test. Initiation of a gluten-free diet rapidly reversesthe mucosal lesion and correctsmalabsorption with symptomatic improvement ${ }^{4,5}$.

Department of Internal Medicine of the Federal University of Ceará, Fortaleza CE, Brazil (UFC); ${ }^{1}$ Doutor em Neurologia e Professor Adjunto da Disciplina de Clínica Médica da UFC; ${ }^{2}$ Estudante de Medicina da UFC; ${ }^{3}$ Médico Assistente do Hospital Universitário Walter Cantídio da UFC; ${ }^{4}$ Médica Assistente da Disciplina de Neurologia da Escola Paulista de Medicina, São Paulo SP, Brazil (UNIFESP-EPM)

Received 18 February 2004, received in final form 4 May 2004. Accepted 3 J ulho 2004.

Dra. Gisele Sampaio Silva - Rua Maria Figueiredo 230/122 - 04002-000 São Paulo SP - Brasil. 
Neurological complicationsare estimated to ocaur in 6 to $10 \%$ of patients with $C^{5}$. Recently a high proportion of patients with neurological symptoms of unknown origin were found to have gluten sensitivity ${ }^{6}$. Cerebellar ataxia, epilepsy, neuropathy, dementia and multifocal leucoencephalopathy have all been described ${ }^{7-10}$. Only exceptionally these syndromesimproved with gluten restriction ${ }^{4}$ and, in some patients, the neurological manifestations even progress despite resolution of both pathologic findings and intestinal symptoms ${ }^{4}$.

We report three cases of patientswith predominant neurological symptoms who had a diagnosis of previously unsuspected CD.

\section{CASES}

Case 1 - A 40-year-old woman was admitted to the hospital because of severe intention tremor and gait dis order that started four years ago. Routine blood examination revealed only a microcytic anemia and decreased ceruloplasmin levels. Computed tomographicscan of the brain wasnormal. The patient wastreated with penicillamine for Wilson's disease. One year later, myoclonus and dysarthria occurred. Some weeks afterwards, the patient presented diarrhea and important weight loss. The laboratory findings showed a slight reduction of serum vitamin E, B12 and folic acid. Ceruloplasmin level was normal. Tests for antiendomysium and IgA antigliadin were negative, but IgG antigliadin washighly positive. Sudam III and xylose tests showed malabsorption. A small intestine biopsy demonstrated the classic histological lesion of untreated CD (villous atrophy, crypt hyperplasia and inflammatory-cell infiltrates). The patient was placed on a gluten-free diet with improvement of the gastrointestinal symptoms. In the following year, intention tremor, ataxic gait, myoclonus and dysarthria were associated with terminal dysmetria, inferior limbs paresis and incoordination. Magnetic resonance imaging (MRI) of the brain demonstrated marked cerebellar atrophy. Despite the normalization of vitamin levels, the patient remains with neurological symptoms.

Case 2 - A 24 year-old woman was first seen in 1999 for epilepsy. She had had complex-partial crises for one year. Her physical and neurological examinations were unremarkable at that time. A MRI showed multiple white matter hyperintensities on T2-weighted images and a left frontal lesion that enhanced after gadolinium administration. She was treated for neurocysticercosis based on serologic and cerebrospinal fluid reactions. Oxcarbazepine was initiated. One year later, she developed inattention, learning difficulties and postural tremors. At that time, she was using divalproate sodium because of intolerance to oxcarbazepine. A MRI was repeated and showed a cicatricial left frontal lesion and the same white matter abnormalities. Topiramate was

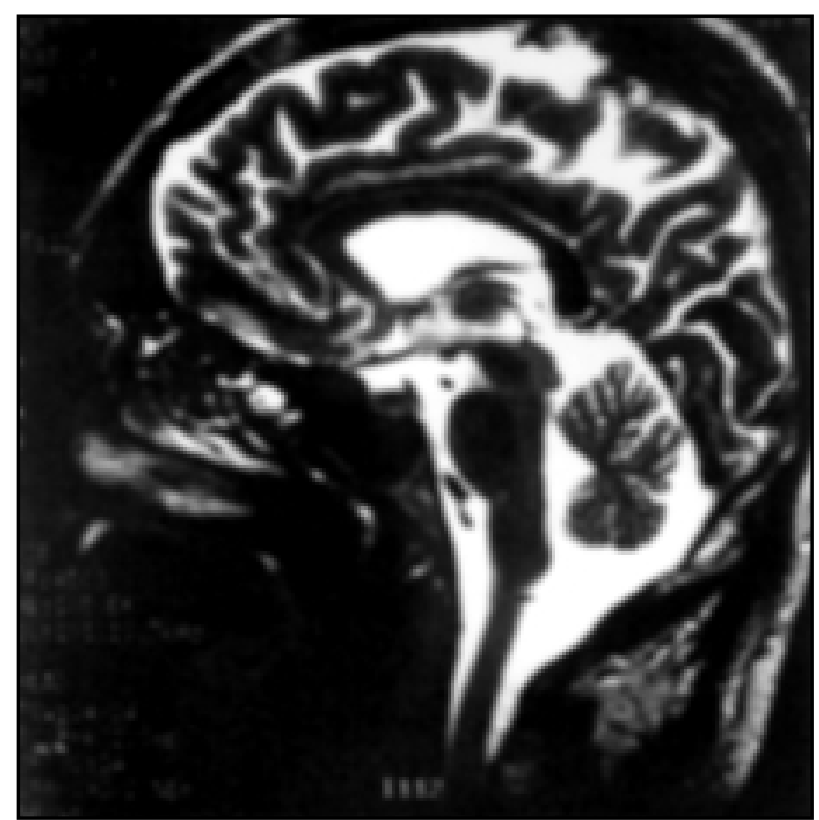

Fig 1. Sagital T1-weighted scan showing important cortical atrophy.

substituted for divalproate and the tremor and cognitive symptoms improved, but did not resolve. She started loosing weight progressively and did not improve after discontinuing topiramate. At that time, tests for antigliadin antibody were highly positive and a small intestine biopsy showed important villous atrophy. She gained weight with a gluten-free diet. One year later, she discontinued the diet and persisted with mild cognitive symptoms, but did not have epileptic crises again.

Case 3 - A 45 year-old man wasfirst seen in 2001 because of memory loss and inability to work for one year. Hisneurological examination wasunremarkable except for a mini-mental examination (MME) of 22, an important delay in answering simple questions and difficulty in naming objects. He had a previous history of chronic diarrhea that was never investigated. A high titer of antiendomysium antibody was detected and a small bowel biopsy showed inflammatory changes. Neurocognitive evaluation revealed inattention, evocation deficits, impaired verbal fluency and disturbed visual and verbal memories. A brain MRI showed cortical and cerebellar atrophy (Fig1). He was placed on a gluten-free diet and gastrointestinal symptoms resolved, but he persisted with an important cognitive impairment. Eighteen monthslater a new neuropsychological evaluation showed progression of the deficits. The patient is now stable with a new brain MRI similar to the previousone and a MME of 25 obtained in his last visit.

\section{DISCUSSION}

Neurological disordersassociated with gastrointestinal (GI), pancreatic, or liver diseases are poor- 
ly recognized. In consequence, their diagnosis and treatment are often unnecessarily delayed. Malabsorption is a word used to describe disordersin which ingested nutrients are not completely absorbed. These conditions can cause neurological abnormalities both through specific nutritional deficiencies and through multisystem involvement associated with specific disorders ${ }^{11}$. The differential diagnosis of mucosal malabsorption disorders is quite broad and include: $C D$, nongranulomatous ulcerative jejunoileitis, eosinophilic gastroenteritis, Crohn's disease, radiation enteritis, immunoproliferative small intestinal disease and chronic mesenteric ischemia ${ }^{12}$.

CD may present with numeral neurological manifestations even without clinical evident malabsorption of nutrients. Although neurological symptoms are rare in children, as many as 36 percent of adult patients have been reported to have neurological manifestations ${ }^{13}$. Cerebellar ataxia, dementia and myoclonus make up the central nervoussystem manifestation sof CD. The neuromuscular manifestations of CD include polymyositis, dermatomyosistis and inclusion-body myositis ${ }^{4}$.

The diagnostic test for celiac disease is a small intestine biopsy that shows loss of vili and flattening of the mucosa, which in is formed of cuboidal cells instead of the normal columnar cells. The cryptsare elongated and inflammatory cellscan be shown. The screening test for CD is the measurement of circulating antigliadin, antiendomysial and antitransglutaminase antibodies ${ }^{5}$.

It is well known that CD may be associated with sporadic and hereditary ataxias ${ }^{8}$. Our first patient has a six-year history of cerebellar ataxia. Only one year after the presentation of the neurological symptoms, she started to manifest gastrointestinal complaints.

Neuropathologic findingsin autopsy of patients with gluten ataxia showed perivascular cuffing with inflammatory cells, predominantly affecting the cerebellum, resulting in loss of Purkinje cells. This suggeststhat the neurological insult may be immune mediated $^{14}$. Hadjivassiliou et al. showed that in patients with gluten ataxia antigliadin antibodies cross-react with epitopeson Purkinje cells $s^{15}$. Recently, it has been suggested that both humoral and cellmediated responses play a part in the pathogenesis of gluten ataxia ${ }^{16}$. Gluten ataxia is primarily a slowly progressive ataxia, and aggressive cerebellar degeneration isthe exception rather than the rule ${ }^{16}$.
Epilepsy is another neurological complication of $\mathrm{CD}^{17}$. Many authors described the association of cerebral calcification, $C D$ and seizures ${ }^{18}$. Although various hypotheses have been proposed, ranging from free radical accumulation with oxidative stressto toxin deposition, the precise mechanismsfor such association remains unknown. CD must be considered in selected patientswith medically refractory seizures since potential alternative therapiescan be helpful ${ }^{6}$. Cross-sectional MRI characteristics have been reported in a few cases of CD associated with neurologic complications. The evolution of cerebral involvement in the course of $C D$ using serial MRIs was described in a case of relapsing-progressive symptomsincluding brainstem and cerebellar involvement. In thiscase the multiple enhancing lesions on the first MRI were favorably modified by steroid treatment, suggesting the presence of an immunologic process ${ }^{19}$. Our patient had a brain MRI that showed multiple white matter hyperintensities on T2-weighted images and a left frontal lesion that enhanced after gadolinium administration. White matter abnormalities allows differential diagnosis with a wide spectrum of disorders such as: multiple sclerosis, cerebral vasculitis, neurosarcoidosis, Sjögren disease, infectious (Lyme and Whipple) and inherited (adrenoleucodystrophy and metachromatic leucodysthrophy) disorders ${ }^{20}$.

Cognitive and psychiatric disturbances were also described in patients with $C^{21}$. While the burden of any chronic disease issufficient to cause a mood alteration, studies suggest a distinct profile among patients with $C^{22}$. Pathophysiology of such clinical signs remains to be determined, but the role of an eventual tissue specific transglutaminase, like in dermatitis herpetiformis, may be suggested. Vitamin B12 deficiency has been associated with hematological, neurological and psychiatric symptoms. Although the terminal ileum is relatively spared in CD, vitamin B12 deficiency is not unusual in untreated CD patients. An immunologic etiology can not be ruled out in patents with $C D$ and cognitive deficits ${ }^{21}$. A study including 33 Alzheimer's patients and 24 controls showed that the prevalence of $C D$ in Alzheimer's disease (AD) is not higher than in cognitively unimpaired elders, suggesting that the immune changes in CD are unlikely to play a role in $A D^{22}$.

Antigliadin antibodies have been found in the cerebrospinal fluid in patients with gluten sensitivity and neurological dysfunction ${ }^{23}$. Nevertheless, these antibodies are present in almost all patients 
with $C D$, but only a small proportion of them develop neurological symptoms. One hypothesismay be that antigliadin antibodies only become neurotoxic if they gain access to the central nervoussystem ${ }^{15}$.

Our cases demonstrate that neurological symptoms may be the first manifestations of CD and may not respond to or even progress during a glutenfree diet. Accurate diagnosis of $C D$ is challenging because gastrointestinal symptoms may be entirely absent or may be overshadowed by extraintestinal complaint ${ }^{24}$. An increased prevalence of CD has been reported in neurological disorders of unknown etiology. A recent study showed that the frequency of undiagnosed CD might be ashigh as $16 \%$ in patients with neurological manifestations of unknown origin ${ }^{8}$. Pathogenic mechanisms of neurological dysfunction in $C D$ remain uncertain. Nowadays, the immune, rather than the nutritional changes of $C D$, are given more credit in the literature ${ }^{8,14}$. In fact, neurological symptoms are found with or without histologic evidence of $C D$, gastrointestinal symptoms or malabsorption signst.

The mucosal lesion and clinical gastrointestinal symptoms recover on gluten-free diet ${ }^{1}$. However, the effect of gluten elimination on neurological manifestations is not very clear. The duration of gluten exposure may be important, but the correlation in a large series was not significant ${ }^{4}$. A long diagnostic delay of $\mathrm{CD}$ or poor dietary compliance may be harmful for the overall outcome and lead to severe complications. This report emphasizes the importance of investigating CD in patients with neurological disorders of unknown origin.

\section{REFERENCES}

1. Farrel RJ, Kelly CP. Celiac sprue. N Engl J Med 2002;346:180-188.

2. Nelsen DA Jr. Gluten-sensitive enteropathy (celiac disease): more common than you think. Am Fam Physician 2002;66:2259-2266.
3. De Santis A, Addolorato G, Romito A, et al. Schizophrenic symptoms and SPECT abnormalities in a coeliac patient: regression after a glutenfree diet. J Intern Med 1997;242:421-423.

4. Wills AJ, Unsworth DJ. The neurology of gluten sensitivity: separating the wheat from the chaff. Curr Opin Neurol 2002;15;519-523.

5. Lagerqvist C, Ivarsson A, Juto P, Persson LA, Hernell O. Screening for adult coeliac disease - which serological marker(s) to use? J Intern Med 2001;250:241-248.

6. Walker Smith JA, Guandalini S, Schmitz J,et al. Revised criteria for diagnosis of celiac disease. Arch Dis Child: 1990;65:909-911.

7. Chin RL, Sander HW, Brannagan TH, et al. Celiac neuropathy. Neurology 2003; 60:1581-1585.

8. Hadjivassiliou M, Gibson A, Davis-Jones GAB, Lobo JA, Stephenson TJ, Milford-Ward A. Does cryptic gluten sensitivity play part in neurological illness? Lancet 1996;347:369-371.

9. Hadjivassiliou M, Grunewald RA, Chattopadhyay AK, et al. Clinical, radiological, neurophysiological, and neuropathological characteristics of gluten ataxia. Lancet 1998;352:1582-1585.

10. Gobbi G, Bouquet F, Greco L, et al. Celiac disease, epilepsy and cerebral calcifications. Lancet 1992;340;439-443.

11. Pallis CA, Lewis PD. The neurology of gastrointestinal disease. London: WB Saunders 1974.

12. Marousi CG, Cerda JJ. Malabsorption: a clinical update. Compr Ther 1997;23:672-678.

13. Banerji NK, Hurwitz LJ. Neurological manifestations in adult steatorrhoea (probable gluten enteropathy). J Neurol Sci 1971;14:125-128.

14. Shill HA, Alaedini A, Latov N, Hallett M. Anti-ganglioside antibodies in idiopathic and hereditary cerebellar degeneration. Neurology 2003;60:1672-1673.

15. Hadjivassiliou M, Boscolo S, Davies-Jones GAB, et al. The humoral response in the pathogenesis of gluten ataxia. Neurology 2002;58;1221-1226.

16. Hadjivassiliou M, Williamson CA, Woodroofe, N M. The humoral response in the pathogenesis of gluten ataxia: reply from the authors. Neurology 2003;60:1397-1399.

17. Santos $\mathrm{CH}$, Almeida IL, Gomes MD, et al. Bilateral occipital calcification, epilepsy and coeliac disease: case report. Arq Neuropsiquiatr 2002;60:840-843.

18. Pratesi R, Gandolfi L, Martins RC, Tauil PL, Nobrega YK, Teixeira WA. Is the prevalence of celiac disease increased among epileptic patients? Arq Neuropsiquiatr 2003;61:330-334.

19. Beyenburg S, Scheid B, Deckert-Schlüter M, Lagrèze HL. Chronic progressive leukencephalopathy in adult celiac disease. Neurology 1998;50:820-822.

20. Scolding N. The differential diagnosis of multiple sclerosis. Neurology in practice 2001;71:9-15.

21. Collin P, Pirttila T, Nurmikko T, Somer H, Erila T, Keyrilainen O. Celiac disease, brain atrophy, and dementia. Neurology 1991;41:372-375.

22. Frisoni GB, Carabellese N, Longhi M, et al. Is celiac disease associated with Alzheimer's disease? Acta Neurol Scand 1997;95:147-151.

23. Chinnery PF, Reading PJ, Milne D, et al. CSF antigliadin antibodies and the Ramsay Hunt syndrome. Neurology 1997;49:1131-1133.

24. Trier JS. Diagnosis of celiac sprue. Gastroenterology 1998;115:211-216. 